\title{
Effect of emulsifying salts on the physicochemical properties of processed cheese made from Mozzarella
}

\author{
L. Chen ${ }^{1}$ and H. Liu \\ Key Laboratory of Food Nutrition and Safety, Tianjin University of Science and Technology, Ministry of Education, Tianjin, China 300457
}

\begin{abstract}
The aim of this study was to investigate the effect of different types and concentrations of emulsifying salts (trisodium citrate, tetrasodium pyrophosphate, sodium tripolyphosphate, sodium hexametaphosphate, and disodium orthophosphate) on the physicochemical properties of processed cheese. The physicochemical composition, texture profile, degree of casein dissociation, fat particle size, color, and nuclear magnetic resonance profile (NMR) of processed cheese were determined. Hardness, degree of casein dissociation, and $\mathrm{pH}$ increased as the concentration of emulsifying salts increased. The fat particle size of processed cheese was significantly influenced by the type of emulsifying salts, with processed cheese made with sodium hexametaphosphate having larger particles $(4.68 \mu \mathrm{m})$ than cheeses made with the other salts (from 2.71 to 3.30 $\mu \mathrm{m})$. The processed cheese prepared with trisodium citrate was whiter than those prepared with the other emulsifying salts. The NMR analysis showed that the relaxation time of processed cheese of 10 to $100 \mathrm{~ms}$ accounted for a major proportion, indicating that the moisture in processed cheese was mainly bound water combined with the fat globule and hydrated casein.
\end{abstract}

Key words: processed cheese, emulsifying salt, physicochemical properties

\section{INTRODUCTION}

Processed cheese differs from natural cheese in that it is not made directly from milk. Processed cheese is produced by blending natural cheese of different ages and degrees of maturity in the presence of emulsifying salts and other dairy and nondairy ingredients, followed by heating and continuous mixing to form a homogeneous product with an extended shelf life (Meyer, 1973; Thomas, 1973; Caric et al., 1985; Guinee et al., 2004). In contrast to natural cheese, processed cheese can be described as a stable oil-in-water emulsion. The

Received February 28, 2012.

Accepted May 13, 2012.

${ }^{1}$ Corresponding author: lingchen332689289@163.com consistency of processed cheese is influenced by many factors, including type and maturity of natural cheeses used, $\mathrm{pH}$ of cheese melting, type and concentration of emulsifying salt, processing conditions, DM content, fat content, presence and concentration of ions (especially calcium), and use of hydrocolloids (Marchesseau et al., 1997; Bowland and Foegeding, 2001; Guinee et al., 2004; Lee et al., 2004; Piska and Stetina, 2004; Shirashoji et al., 2006a; Dimitreli and Thomareis, 2007; Gustaw and Mleko, 2007; Lu et al., 2007; Cerníková et al., 2008).

Emulsifying salts (ES) are an important ingredient in processed cheese manufacture. Emulsifying salts are ionic compounds made up of monovalent cations and polyvalent anions. The 2 primary functions of emulsifying salts in processed cheese manufacturer are $\mathrm{pH}$ adjustment and calcium sequestering, which improve the emulsification properties of caseins by sequestering the calcium from the insoluble calcium-paracaseinate phosphate network present in natural cheese. The sequestered complexes disrupt the major molecular forces that cross-link the various monomers of casein in the network. This disruption, in conjunction with heating and mixing, leads to hydration and partial dispersion of the protein system. Casein dispersion and hydration can help emulsification by coating the surfaces of dispersed free fat globules (Guinee et al., 2004).

According to the US Food and Drug Administration (FDA, 2011), 13 emulsifying salts are approved for use (alone or in combination) in processed cheese manufacture (Code of Federal Regulations, 21CFR 133.169133.180). Sodium phosphates, polyphosphates, and citrates represent the most commonly used. In a study on the effect of type of ES, Shirashoji et al. (2006a) produced sliced processed cheeses using 4 ES: trisodium citrate (TSC), disodium orthophosphate (DSP), sodium hexametaphosphate (SHMP), and tetrasodium pyrophosphate (TSPP), at $2.5 \%$ each without $\mathrm{pH}$ adjustment. They determined processed cheese $\mathrm{pH}$, flowability, meltability, and texture of the processed cheeses. The $\mathrm{pH}$ of the processed cheese made using SHMP was significantly lower ( $\mathrm{pH} 5.3)$ than that of the other processed cheeses ( $\mathrm{pH} 5.9$ to 6.0 ). The results of the texture evaluation indicated that processed cheese made using DSP and SHMP tended to have a mushy 
and crumbly texture, whereas processed cheese made with TSPP had a tough and rubbery texture. In the study of Fox et al. (2000), citrates were found to bind calcium weakly and show low peptization (the ability to form stable dispersions of colloidal particles in water), whereas other studies have shown that TSC results in excellent calcium chelating ability and casein peptization properties (Cavalier-Salou and Cheftel, 1991; Mizuno and Lucey, 2005).

Although ES are widely used in the manufacture of processed cheeses, one of the most common questions when selecting of ES for processed cheese manufacture relates to calcium-sequestering ability, but the interaction of ES with calcium and casein is not fully understood. Because of differences in experimental conditions, including type and age of natural cheese used, differences in processed cheese formulation and composition, and differences in processing conditions used for processed cheese manufacture, the literature presents few and often conflicting results about the effects of the interaction of emulsifying salts with calcium and casein on cheese physicochemical properties.

The objective of this study was to investigate the effect of different types and concentration of ES: TSC, TSPP, sodium tripolyphosphate (STPP), DSP, and SHMP, on the physicochemical properties of processed cheese.

\section{MATERIALS AND METHODS}

\section{Materials}

The following ingredients were used to manufacture processed cheese: (1) natural cheese: 1-mo-old and 4-moold Mozzarella cheese made in our laboratory, at a ratio of 2:1 (wt/wt); (2) fat source: butter (Bright Dairy \& Food Co. Ltd., Shanghai, China); (3) whey protein concentrate (WPC; Ba'Emek Advanced Technologies Ltd., Afula, Israel); (4) skim milk powder (Dairy Products Co. Ltd., Auckland, New Zealand); and (5) emulsifying salts: TSC $\left(\mathrm{Na}_{3} \mathrm{C}_{6} \mathrm{H}_{5} \mathrm{O}_{7} \cdot 2 \mathrm{H}_{2} \mathrm{O}\right.$; Northern Alliance Fine Chemicals Development Co. Ltd., Tianjin, China), STPP $\left(\mathrm{Na}_{5} \mathrm{P}_{3} \mathrm{O}_{10}\right.$; Chemical Reagent Factory, Tianjin, China), TSPP $\left(\mathrm{Na}_{4} \mathrm{P}_{2} \mathrm{O}_{7}\right.$; Institute of Chemical Reagent, Tianjin, China), SHMP $\left[\left(\mathrm{NaPO}_{3}\right)_{\mathrm{n}}, 10 \leq \mathrm{n} \leq\right.$ 25 ; Institute of Chemical Reagent], or DSP $\left(\mathrm{Na}_{2} \mathrm{PO}_{4}\right.$; Institute of Chemical Reagent).

\section{Processed Cheese Manufacture}

The formulation of processed cheese for this work typically contained around $22 \%$ protein, $30 \%$ fat, and $43 \%$ moisture. Processed cheeses were prepared with a Blentech twin-screw cooker (Blentech Corp., Rohnert
Park, CA) equipped with direct and indirect steam injection. Mozzarella cheeses were tempered overnight at room temperature $\left(\sim 25^{\circ} \mathrm{C}\right)$ and chopped using a knife. The processed cheese cooker was preheated to $80^{\circ} \mathrm{C}$ for $1 \mathrm{~min}$; then, $8.0 \mathrm{~kg}$ of grated cheese, distilled water, and $\mathrm{ES}(\leq 3 \%$, wt/wt; $5 \mathrm{ES} \times 5$ concentrations: 1, 1.5, 2, 2.5 , and $3 \%$, amounting to 25 groups of experimental cheeses) were added to the cooker and mixed at 50 rpm for $40 \mathrm{~s}$. During mixing, a minute amount of critic acid was added to adjust the $\mathrm{pH}$ of the final product to approximately 5.7. After mixing, the cheese was stirred at $100 \mathrm{rpm}$ and heated by direct steam injection for $100 \mathrm{~s}$; after that, indirect steam was used to continue heating to $95^{\circ} \mathrm{C}$. Holding times at $95^{\circ} \mathrm{C}$ ranged from 3 to $8 \mathrm{~min}$. Cheese was poured into $0.5-\mathrm{kg}$ pouches and stored at $4^{\circ} \mathrm{C}$ overnight (Shirashoji et al., 2006b). The texture, fat particle size, color, nuclear magnetic resonance (NMR) profile, and compositional analyses were determined $24 \mathrm{~h}$ after manufacture.

\section{Cheese Composition}

The samples of processed cheese were evaluated in triplicate with respect to the following physicochemical parameters: $\mathrm{pH}$ using a $\mathrm{pH}$ meter (SC310, Ohaus Corp., Parsippany, NJ) with a combined glass electrode at room temperature; moisture content, determined by a gravimetric method according to ISO (2004; method 5534:2004); total nitrogen by the Kjeldahl method according to method 991.20 (AOAC, 1997); NPN by the Kjeldahl method according to method 991.21 (AOAC, 1997); total protein, by multiplying total $\mathrm{N}$ by a conversion factor of 6.38; and fat content according to RöseGottlieb method (China Ministry of Health, 2010).

\section{Degree of Casein Dissociation}

The processed cheeses were evaluated with respect to the nonsedimented nitrogen content (NSN), determined in the supernatant formed after ultracentrifugation $\left(7,763 \times \mathrm{g}, 10 \mathrm{~min}, 20^{\circ} \mathrm{C}\right)$ of a dispersion of 5 $\mathrm{g}$ of product in $95 \mathrm{~mL}$ of distilled water (Heertje et al., 1981; Marchesseau and Cuq, 1995). The degree of casein dissociation (DCD) was determined from the NSN content, as follows:

$$
\mathrm{DCD}=\frac{\mathrm{NSN}-\mathrm{NCN}}{\mathrm{TN}-\mathrm{NCN}} \times 100 \%
$$

where $\mathrm{TN}$ is total nitrogen and $\mathrm{NCN}$ is noncasein nitrogen. The DCD corresponds to the proportion of caseinate present in the form of monomers or oligomers in the casein (Cavalier-Salou and Cheftel, 1991). 


\section{Texture Profile Evaluation}

The textural properties of processed cheese were evaluated by the method of texture profile analysis (TPA; Bourne, 2002). The day preceding the analysis, the samples were maintained in a refrigerator at $4^{\circ} \mathrm{C}$. The texture profile was determined by allowing the probe to penetrate $10 \mathrm{~mm}$ into the sample at a speed of $1 \mathrm{~mm} / \mathrm{s}$. Compression was interrupted when it reached the $10-\mathrm{mm}$ point, and the probe returned to its original position. This was followed by a second compression cycle, the probe again penetrating $10 \mathrm{~mm}$ into the sample at a speed of $1 \mathrm{~mm} / \mathrm{s}$, compression again being interrupted when it reached the $10-\mathrm{mm}$ point, and the probe returned to its original position. The data for force as a function of time were obtained for the 2 compression-decompression cycles, and using the "texture profile" function of the TAXT2 software (Stable Micro Systems Ltd., Surrey, UK), and values for the following parameters were obtained: hardness, springiness, gumminess, and adhesiveness. All determinations were carried out in quadruplicate.

\section{Evaluation of Fat Particle Size}

A sample of processed cheese $(0.5 \mathrm{~g})$ was dispersed in a solution $(50 \mathrm{~mL})$ containing EDTA $(0.375 \% \mathrm{wt} /$ wt) and Tween $20(0.125 \% \mathrm{vol} / \mathrm{vol})$, and the $\mathrm{pH}$ was adjusted to 10 using $1 \mathrm{~mol} / \mathrm{L}$ sodium hydroxide (Walstra 1965). After standing overnight in a refrigerator $\left(4^{\circ} \mathrm{C}\right)$, the samples were allowed to equilibrate to room temperature for $1 \mathrm{~h}$. The resulting suspensions were then read in a laser diffraction particle size analyzer (model LS13 320, Beckman Coulter Ltd., Brea, CA). The particle size $[\mathrm{D}(3,2)]$ obtained was the average particle diameter, calculated as the ratio between volume and total surface area. The distribution of the fat particle sizes was also obtained and used to compare the range of particle sizes. Each sample was measured in duplicate.

\section{Color Evaluation}

The instrumental color evaluation of samples was obtained by using a spectrophotometer CM-3600A (Konica Minolta, Tokyo, Japan) at room temperature with a 20-mm-diameter steel plate. The height of the sample was set at $5 \mathrm{~mm}$. The color scale used was the CIELAB ( $\left.\mathrm{L}^{*}, \mathrm{a}^{*}, \mathrm{~b}^{*}\right)$ with illuminant D65 and observer angle of $10^{\circ}$. The value $\mathrm{L}^{*}$ represents the sample luminosity, varying from 0 (black) to 100 (white); the value $\mathrm{a}^{*}$ represents color, varying from red $(+)$ to green $(-)$; and the value $\mathrm{b}^{*}$ also represents color, varying from yellow $(+)$ to blue $(-)$. In addition to the values for $\mathrm{L}^{*}, \mathrm{a}^{*}$, and $\mathrm{b}^{*}$, the values for the whiteness index (Hunter) and the yellowness index [YI 1925 (2/C)] were obtained, as calculated by the equipment.

\section{NMR Proton Relaxation}

Low-field NMR relaxation measurements were performed on a Niumag Benchtop Pulsed NMR Analyzer PQ001 (Niumag Electric Corp., Shanghai, China) operating at a resonance frequency for protons of 21.96 MHz. Approximately $1.5 \mathrm{~g}$ of sample was placed in a 15-mm glass tube and inserted in the NMR tube. Spin-spin relaxation time $\left(\mathbf{T}_{2}\right)$ was measured using the Carr-Purcell-Meiboom-Gill sequence. The $\mathrm{T}_{2}$ measurements were made with a $\tau$-value (time between $90^{\circ}$ and $180^{\circ}$ pulses) of $100 \mu \mathrm{s}$. Data from 8,000 echoes were acquired as 32 scan repetitions. The repetition time between subsequent scans was 3,000 ms. Each measurement was performed in quadruplicate. Postprocessing of the NMR $\mathrm{T}_{2}$ data distributed exponential fitting of Carr-Purcell-Meiboom-Gill decay curves was performed using Multi-Exp Inv Analysis software (Niumag Electric Corp.).

\section{Statistical Analyses}

Statistical analyses of results were performed using SPSS 17.0 (SPSS Inc., Chicago, IL). Analysis of variance was used to determine the significance of main effects.

\section{RESULTS AND DISCUSSION}

\section{Composition, $\mathrm{pH}$, and $\mathrm{DCD}$}

The contents of moisture, fat, and protein, and the $\mathrm{pH}$ of the natural cheese are shown in Table 1. Figure 1 shows the $\mathrm{pH}$ value of processed cheese prepared with different types of ES. The $\mathrm{pH}$ values of the cheeses prepared with DSP and SHMP were significantly lower compared with those of other cheeses, and the $\mathrm{pH}$ of the cheese produced with TSPP was greater than that containing TSC. The acidity of cheese made with SHMP was significantly greater, but we found no significant differences in acidity among the other cheeses. The results obtained for $\mathrm{pH}$ are in agreement with those of Dimitreli et al. (2005) for processed cheeses prepared with the same emulsifying agents. According to the literature, the optimal $\mathrm{pH}$ for obtaining suitable structural and sensory properties of processed cheese should range between 5.5 and 6.0 (Marchesseau et al., 1997; Lee and Klostermeyer, 2001; Guinee et al., 2004; $\mathrm{Lu}$ et al., 2007). According to Fox et al. (2000), the buffering capacity of sodium salts in the $\mathrm{pH}$ range nor- 


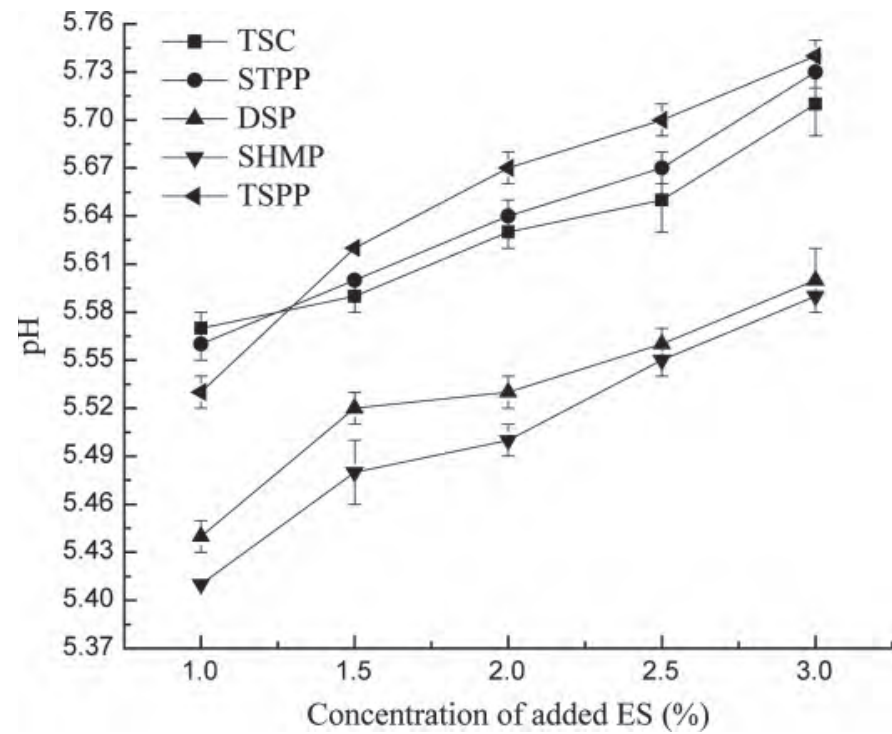

Figure 1. Influence of addition of different emulsifying salts (ES) on $\mathrm{pH}$ values of processed cheese. TSC $=$ trisodium citrate; TSPP $=$ tetrasodium pyrophosphate; STPP = sodium tripolyphosphate; SHMP = sodium hexametaphosphate; DSP = disodium orthophosphate.

mally found in processed cheeses (5.5 to 6 ) decreases with an increase in chain size and is practically zero for long-chain phosphates $(\mathrm{n}>10)$ such as SHMP. On the other hand, TSC showed good buffering capacity in the range between $\mathrm{pH} 5.3$ and 6 . The $\mathrm{pH}$ of processed cheeses is related to the $\mathrm{pH}$ of the ES in solution and to its buffering capacity. In general, if the salts are in the same concentration, the $\mathrm{pH}$ of the final product decreases in the following order: TSPP $\approx \mathrm{STPP} \approx \mathrm{TSC}$ $>$ SHMP (Fox et al., 2000), which is in agreement with the results obtained here. Generally, the ES changes the $\mathrm{pH}$ of the cheese blend (Molins, 1991; Guinee et al., 2004; Mulsow et al., 2007).

Figure 2 shows the DCD of the processed cheeses prepared with different types of ES. The DCD is related to the ability of the ES to sequester calcium (Dimitreli et al., 2005). The sample prepared with SHMP showed a significantly lower value than the other processed cheeses, which did not differ from each other. According to Mizuno and Lucey (2005), some types of phosphate slowly induce protein aggregation by way of the interaction between the dissociated casein molecules

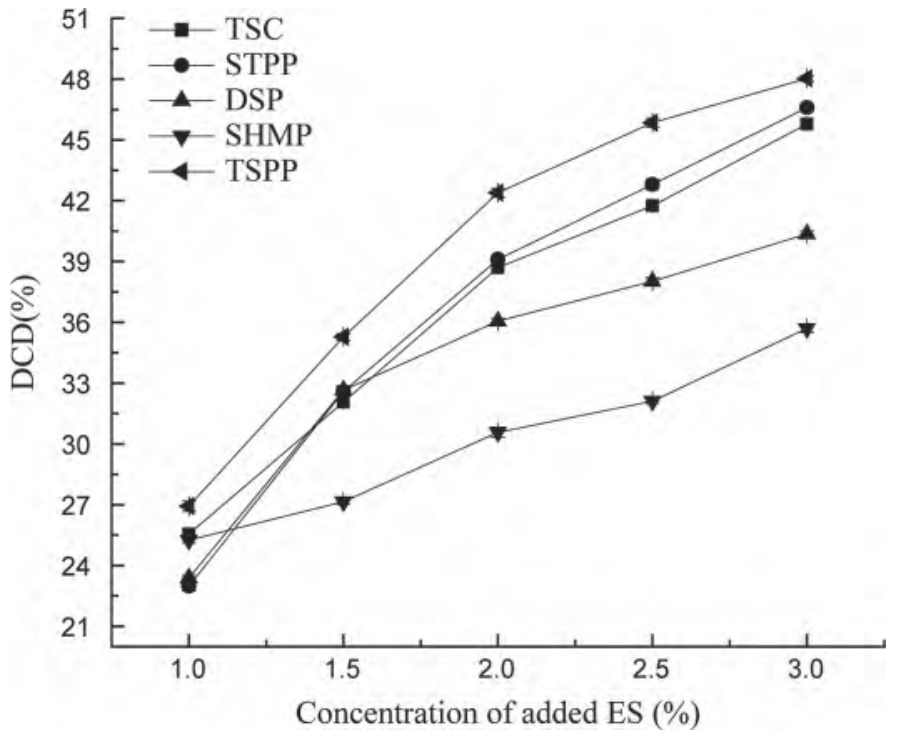

Figure 2. Influence of addition of different emulsifying salts (ES) on the degree of casein dissociation (DCD) of processed cheese. TSC $=$ trisodium citrate; TSPP $=$ tetrasodium pyrophosphate; STPP $=$ sodium tripolyphosphate; SHMP = sodium hexametaphosphate; DSP $=$ disodium orthophosphate.

and the phosphate anions. Because STPP and TSPP contained a similar amount of phosphate anions, the interaction between the dissociated casein molecules was also similar, which would explain why we observed no significant difference between them with respect to DCD.

\section{TPA}

Hardness is defined as the force necessary to attain a given deformation (Szczesniak, 1963). Table 2 shows the mean values obtained for hardness (data for adhesiveness, springiness, and gumminess are not shown) of the processed cheeses prepared with different types of ES. Hardness increased as the concentration of ES increased, and the types of ES significantly influenced the hardness of processed cheeses. Cheeses made with DSP and SHMP presented lower values for hardness than the other cheeses. Cheese made with TSPP showed the highest values for hardness and gumminess, followed by cheese made with STPP, which might be associated

Table 1. Physicochemical characterization of natural Mozzarella cheese used in manufacture of processed cheese $^{1}$

\begin{tabular}{lcccc}
\hline Cheese age & Moisture (\%) & Fat (\%) & Protein (\%) & $\mathrm{pH}$ \\
\hline $1 \mathrm{mo}$ & 51.4 & 22.9 & 23.4 & 5.15 \\
$4 \mathrm{mo}$ & 47.7 & 23.2 & 24.8 & 5.17 \\
\hline
\end{tabular}

${ }^{1}$ Results are means of 3 replicates. 
Table 2. Effects of different emulsifying salts on hardness (g) of processed cheeses (means $\pm \mathrm{SE}$ )

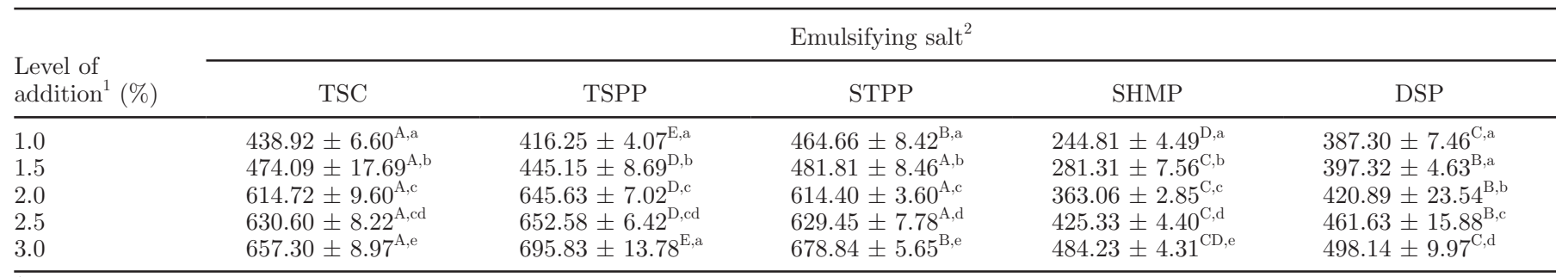

${ }^{\mathrm{A}-\mathrm{E}}$ Means within a row not sharing a common superscript are significantly different $(P<0.05)$.

${ }^{\mathrm{a}-\mathrm{e}}$ Means within a column not sharing a common superscript are significantly different $(P<0.05)$.

${ }^{1}$ The level of addition (1 to $3 \%$ ) was the concentration of the emulsifying salts.

${ }^{2} \mathrm{TSC}=$ trisodium citrate; TSPP $=$ tetrasodium pyrophosphate; $\mathrm{STPP}=$ sodium tripolyphosphate; $\mathrm{SHMP}=$ sodium hexametaphosphate; DSP $=$ disodium orthophosphate.

with fat particle size. According to Savello et al. (1989) and Lee et al. (2004), the smaller the diameter of the globules, the greater the surface area and the number of protein-protein bonds, making the network firmer.

\section{Fat Particle Size}

The fat particle sizes in the processed cheeses prepared with TSC, TSPP, STPP, SHMP, and DSP were $2,71,2.11,2.92,4.68$, and 3.30 , respectively. The fat particle size of the samples was significantly influenced by the type of ES $(P<0.05)$ : processed cheese made with SHMP had larger particles than cheeses made with other ES, which is different from the results reported by Dimitreli et al. (2005), who found that the fat particle sizes of the processed cheese made with SHMP were smaller than those of processed cheeses made with other ES. This difference might be related to the type and age of natural cheese and the different processing conditions. It is possible that SHMP cannot promote effective emulsification because of its lower DCD.

Figure 3 shows the fat particle size distribution in the processed cheeses prepared with different types of ES. Cheese made with SHMP presented a wide range of particle size, whereas the others presented a more homogeneous distribution.

Small fat particle size and an increase in size homogeneity enhance the incorporation of fat into the matrix (Jost et al., 1986). Such fat globules can behave like large protein units and act to reinforce gels by forming a copolymer network (Aguilera and Kinsella, 1991). These protein-coated fat globules can bind more proteins during heating and can assist in gel matrix formation. The greater homogeneity in particle size distribution found for cheese made with TSPP compared with the others was probably related to complex molecular dissociation and reassociation mechanisms induced by the salt.

\section{Color}

Table 3 shows the mean values for the color parameters $\mathrm{L}^{*}, \mathrm{a}^{*}$, and $\mathrm{b}^{*}$ and the white and yellow indices for the processed cheeses prepared with the different types of ES. The type of ES significantly $(P<0.05)$ influenced all color parameters evaluated. The cheese made with TSC were whiter and less yellow than the others, which was related to the smaller fat particle size in this sample.

Generally, yellow color is associated with foods having a high fat content. However, the final color of the processed cheeses depends not only on the fat content,

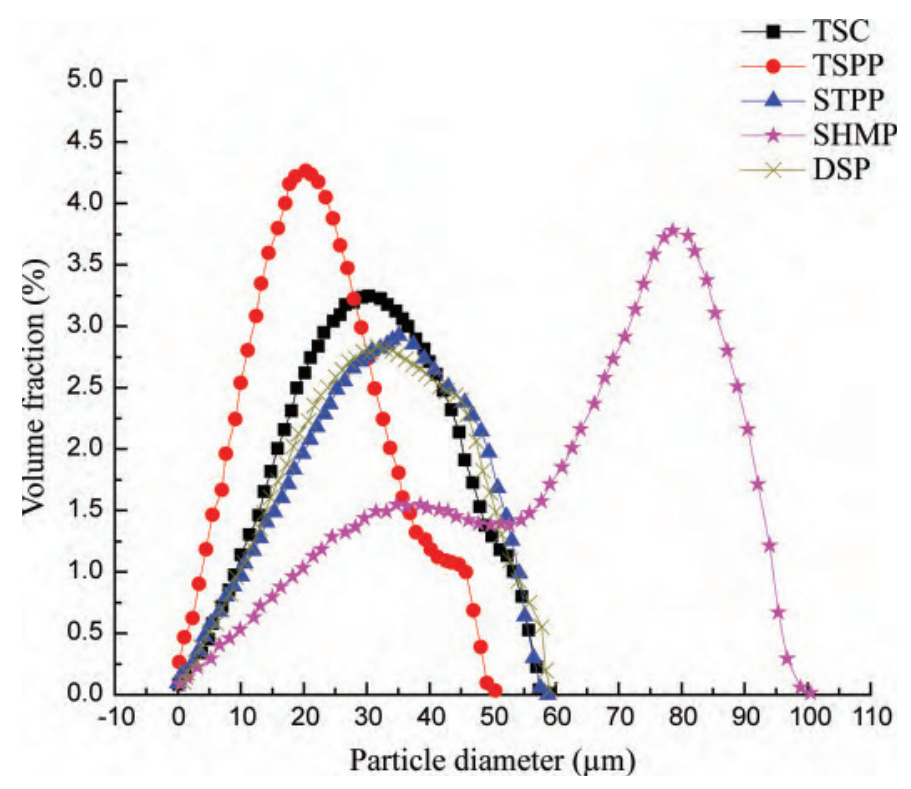

Figure 3. Fat particle size distributions in the processed cheese manufacture with different emulsifying salts (ES). TSC $=$ trisodium citrate; TSPP = tetrasodium pyrophosphate; STPP = sodium tripolyphosphate; SHMP = sodium hexametaphosphate; DSP = disodium orthophosphate. Color version available in the online PDF. 
Table 3. Mean values $(n=3)$ for the color parameters $L^{*}, a^{*}, b^{*}$ (luminosity, red-green, and yellow-blue, respectively), Hunter (whiteness index), and YI D1925 (2/C) (yellowness) for the processed cheese prepared with different emulsifying salts

\begin{tabular}{lrrrrr}
\hline & \multicolumn{5}{c}{ Emulsifying salt $^{1}$} \\
\cline { 2 - 6 } Color parameter & TSC & TSPP & STPP & SHMP & DSP \\
\hline $\mathrm{a}^{*}$ & $3.83^{\mathrm{a}}$ & $3.40^{\mathrm{b}}$ & $3.32^{\mathrm{c}}$ & $3.23^{\mathrm{d}}$ & $3.20^{\mathrm{d}}$ \\
$\mathrm{b}^{*}$ & $11.25^{\mathrm{a}}$ & $11.19^{\mathrm{b}}$ & $10.76^{\mathrm{c}}$ & $10.86^{\mathrm{d}}$ & $11.50^{\mathrm{e}}$ \\
$\mathrm{L}^{*}$ & $61.74^{\mathrm{a}}$ & $54.36^{\mathrm{b}}$ & $52.27^{\mathrm{c}}$ & $53.15^{\mathrm{d}}$ & $54.49^{\mathrm{e}}$ \\
Hunter & $46.66^{\mathrm{a}}$ & $46.05^{\mathrm{b}}$ & $44.57^{\mathrm{c}}$ & $44.43^{\mathrm{c}}$ & $43.96^{\mathrm{d}}$ \\
YI D 1925 (2/C) & $23.96^{\mathrm{a}}$ & $25.89^{\mathrm{b}}$ & $25.86^{\mathrm{b}}$ & $27.76^{\mathrm{c}}$ & $27.05^{\mathrm{c}}$ \\
\hline
\end{tabular}

${ }^{\mathrm{a} e} \mathrm{Means}$ in a row with the same letter do not differ significantly $(P>0.05)$.

${ }^{1} \mathrm{TSC}=$ trisodium citrate; $\mathrm{TSPP}=$ tetrasodium pyrophosphate; $\mathrm{STPP}=$ sodium tripolyphosphate; $\mathrm{SHMP}=$ sodium hexametaphosphate; DSP = disodium orthophosphate.

but also on the size of the fat particles dispersed in the protein matrix. According to McClements (2005), the smaller the fat particle diameter, the whiter the product. The cheeses made with TSPP and STPP showed a low value for whiteness and were more yellow than the cheeses made with TSC. According to Mizuno and Lucey (2005), ES increase the casein dispersion during heating, resulting in a greater number of possible casein-casein interactions upon cooling. When phosphate-based salts are used, interactions between the dissociated casein and the ES can also occur, but this additional interaction does not occur when using citrate-based salts because citrate and casein do not interact. This signifies that the type of colloidal dispersion obtained with citrate was different from that obtained in products made with phosphate-based ES.

\section{NMR Proton Relaxation}

The study of NMR relaxation properties can give relevant information about compartmentalization, the dynamics of water through the measure of transverse relaxation time $\left(\mathrm{T}_{2}\right.$; Bianchi et al., 2004). The $\mathrm{T}_{2}$ relaxation measured in muscle-based foods has been shown to correlate with total water content and it helps in quantifying the influences of ingredients and processing (Barbut and Mittal, 1992; DeFreitas et al., 1997). As shown in Figure 4, the NMR decay curve was fitted to 3 components attributed to bound $\left(\mathrm{T}_{21}\right)$, immobile $\left(\mathrm{T}_{22}\right.$, $\left.\mathrm{T}_{23}\right)$, and bulk water $\left(\mathrm{T}_{24}\right)$. Typically, the signal decay could be fitted into a distributed exponential consisting of 1 or 2 separate peaks. Figure 4 shows distributed $T_{2}$ relaxation times in samples with different types of ES. The $\mathrm{T}_{2}$ was characterized by a minor population with a relaxation time of a few milliseconds and a major population with a relaxation time between 10 and $100 \mathrm{~ms}$.

A statistically significant effect was found for $\mathrm{T}_{2}(P<$ $0.05)$ with the different types of ES in processed cheeses (Table 4). It can be seen that the relaxation time of processed cheese in 10 to $100 \mathrm{~ms}$ accounted for the major proportion, whereas the other relaxation time accounted for a relatively small proportion. The ES used in processed cheese preparation are often considered to act as calcium-chelating and casein-dispersing agents (Caric et al., 1985; Shimp, 1985). During cooking, ES could help to change the calcium phosphate complexes in the insoluble calcium-paracaseinate phosphate network in natural cheese to a soluble sodium caseinate form. The change between $\mathrm{Ca}$ and $\mathrm{Na}$ with heating and shearing leads to hydration and dispersion of the caseinate, where the soluble caseinate covers the fat globules and true emulsification occurs. During the cooling stage, the partially dispersed caseinate matrix forms "flocks," and the flocks subsequently interact to

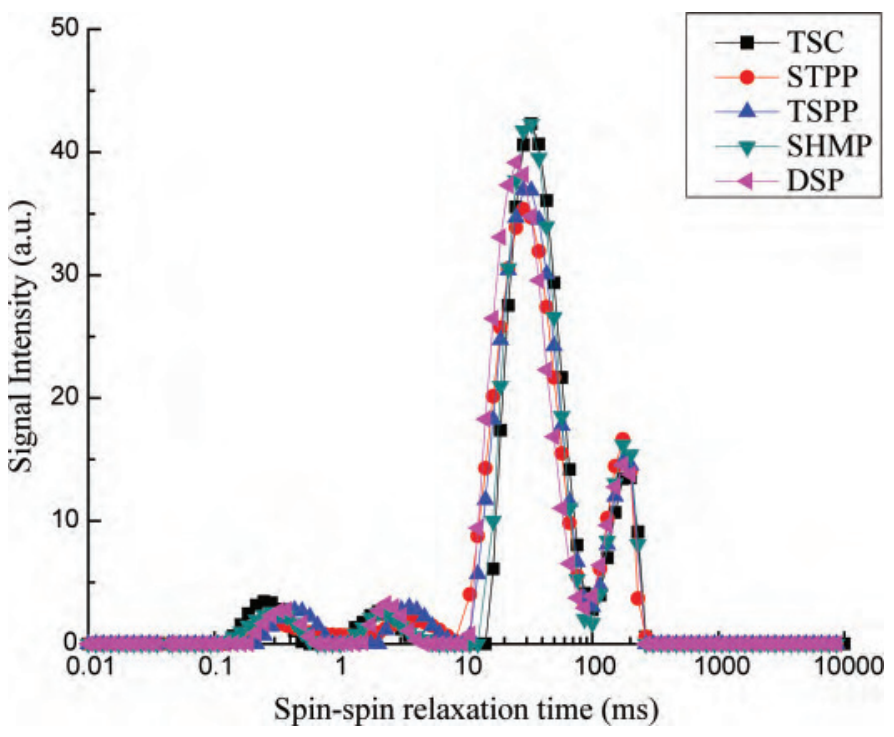

Figure 4. Spin-spin relaxation times $\left(\mathrm{T}_{2}\right)$ of processed cheese prepared with different emulsifying salts $(\mathrm{ES}) . \mathrm{TSC}=$ trisodium citrate; $\mathrm{TSPP}=$ tetrasodium pyrophosphate; $\mathrm{STPP}=$ sodium tripolyphosphate; SHMP = sodium hexametaphosphate; DSP = disodium orthophosphate. Color version available in the online PDF. 
Table 4. Relaxation composition profile $^{1}$ (mean $\pm \mathrm{SD}, \mathrm{n}=3$ ) of cheeses made with different emulsifying salts

\begin{tabular}{lllll}
\hline $\begin{array}{l}\text { Emulsifying } \\
\text { salt }\end{array}$ & \multicolumn{1}{c}{$\mathrm{T}_{21}$} & \multicolumn{1}{c}{$\mathrm{T}_{22}$} & $\mathrm{~T}_{23}$ & $\mathrm{~T}_{24}$ \\
\hline $\mathrm{TSC}$ & $20.61 \pm 2.88^{\mathrm{a}}$ & $15.72 \pm 2.15^{\mathrm{abc}}$ & $326.28 \pm 21.15^{\mathrm{a}}$ & $58.21 \pm 5.83^{\mathrm{a}}$ \\
STPP & $17.46 \pm 2.76^{\mathrm{ab}}$ & $15.01 \pm 1.08^{\mathrm{abc}}$ & $322.80 \pm 0.00^{\mathrm{a}}$ & $68.66 \pm 3.57^{\mathrm{ab}}$ \\
TSPP & $16.48 \pm 1.04^{\mathrm{b}}$ & $16.78 \pm 1.17^{\mathrm{b}}$ & $331.50 \pm 23.28^{\mathrm{a}}$ & $63.05 \pm 4.66^{\mathrm{b}}$ \\
SHMP & $17.88 \pm 1.17^{\mathrm{ab}}$ & $15.02 \pm 2.09^{\mathrm{abc}}$ & $321.90 \pm 0.00^{\mathrm{a}}$ & $65.19 \pm 7.12^{\mathrm{ab}}$ \\
DSP & $15.09 \pm 2.65^{\mathrm{b}}$ & $14.30 \pm 1.26^{\mathrm{c}}$ & $331.57 \pm 19.39^{\mathrm{a}}$ & $70.24 \pm 9.53^{\mathrm{b}}$ \\
\hline
\end{tabular}

${ }^{\mathrm{a}-\mathrm{e}}$ Means within a row with different letters differ significantly $(P<0.05)$.

${ }^{1} \mathrm{~T}_{21}: 0.01$ to $1 \mathrm{~ms} ; \mathrm{T}_{22}: 1$ to $10 \mathrm{~ms} ; \mathrm{T}_{23}: 10$ to $100 \mathrm{~ms} ; \mathrm{T}_{24}:>100 \mathrm{~ms}$.

${ }^{2} \mathrm{TSC}=$ trisodium citrate; $\mathrm{TSPP}=$ tetrasodium pyrophosphate; $\mathrm{STPP}=$ sodium tripolyphosphate; $\mathrm{SHMP}=$ sodium hexametaphosphate; DSP = disodium orthophosphate.

form a uniform, closely knit, gel network (Zhong and Daubert, 2004). Therefore, the processed cheese structure essentially consists of a fat phase evenly dispersed (in the form of fat globules) in a partially dispersed casein gel network. We conclude that the moisture in processed cheese is mainly bound water combined with the fat globule and hydrated casein. The proportion of bound water combined with fat globule and hydrated casein was similar in the processed cheeses prepared with different ES.

\section{CONCLUSIONS}

We investigated the effects of different types of ES on physicochemical properties of processed cheese. Each type of ES interacted differently in the processed cheese model system. Processed cheeses made with TSC and STPP had similar hardness, pH, and DCD, whereas processed cheese made with TSPP had greater hardness, which could be attributed to the better emulsification of fat globules. The processed cheeses made with SHMP and DSP were different from the others, showing more yellow color and relatively lower hardness. This finding could be attributed to the fact that SHMP and DSP were less able than other ES to chelate Ca from the calcium-paracaseinate phosphate network. By NMR measurement, we know that the moisture in processed cheese was mainly bound water combined with the fat globule.

\section{REFERENCES}

Aguilera, J. M., and J. E. Kinsella. 1991. Compression strength of dairy gels and microstructural interpretation. J. Food Sci. $56: 1224-1228$.

AOAC (Association of Official Analytical Chemists). 1997. Official Methods of Analysis of AOAC International. Vol. 2. 16th ed. AOAC Int., Gaithersburg, MD.

Barbut, S., and G. S. Mittal. 1992. Use of carrageenans and xanthan gum in reduced fat breakfast sausages. Lebenson. Wiss. Technol. 25:509-513.

Bianchi, M., F. C. Capozzi, and M. A. Cremonini. 2004. Influence of the season on the relationships between NMR transverse relax- ation data and water-holding capacity of turkey breast meat. J. Sci. Food Agric. 84:1535-1540.

Bourne, M. C. 2002. Food Texture and Viscosity: Concept and Measurement. 2nd ed. Academic Press, New York, NY.

Bowland, E. L., and E. A. Foegeding. 2001. Small strain oscillatory shear and microstructural analyses of a model processed cheese. J. Dairy Sci. 84:2372-2380.

Caric, M., M. Gantar, and M. Kalab. 1985. Effects of emulsifying agents on the microstructure and other characteristics of process cheese - A review. Food Microstruct. 4:297-312.

Cavalier-Salou, C., and J. C. Cheftel. 1991. Emulsifying salts influence on characteristics of cheese analogs from calcium caseinate. J. Food Sci. 56:1542-1547.

Cerníková, M., F. Bunka, V. Pavlínek, P. Brezina, J. Hrabe, and P. Valásek. 2008. Effect of carrageenan type on viscoelastic properties of processed cheese. Food Hydrocoll. 22:1054-1061.

China Ministry of Health. 2010. National food safety standard: Determination of fat in foods for infants and young children, milk and milk products. GB 5413.3-2010. China Ministry of Health, Beijing, China.

DeFreitas, Z., J. G. Sebranek, D. G. Olson, and J. M. Carr. 1997. Carrageenan effects on salt soluble meat proteins in model systems. J. Food Sci. 62:539-543.

Dimitreli, G., and A. S. Thomareis. 2007. Texture evaluation of blocktype processed cheese as a function of chemical composition and in relation to its apparent viscosity. J. Food Eng. 79:1364-1373.

Dimitreli, G., A. S. Thomareis, and P. G. Smith. 2005. Effect of emulsifying salts on casein peptization and apparent viscosity of processed cheese. Int. J. Food Eng. 1:1-15.

FDA (Food and Drug Administration). 2011. 21CFR133.16921CFR133.180: Cheeses and related cheese products: Pasteurized process cheese. Accessed Jun. 6, 2012. http://www.accessdata.fda. gov/scripts/cdrh/cfdocs/cfcfr/CFRSearch.cfm?fr=133.169.

Fox, P. F., T. P. Guinee, T. M. Cogan, and P. L. H. McSweeney. 2000 Processed cheese and substitute or imitation cheese products. Pages 429-451 in Fundamentals of Cheese Science. P. F. Fox, T. P. Guinee, T. M. Cogan, P. L. H. McSweeney, ed. Aspen Publishers, Gaithersburg, MD.

Guinee, T. P., M. Caric, and M. Kalab. 2004. Pasteurized processed cheese and substitute/imitation cheese products. Pages 349-394 in Cheese: Chemistry, Physics and Microbiology. Vol. 2. 3rd ed. P. F. Fox, ed. Elsevier Applied Science, London, UK.

Gustaw, W., and S. Mleko. 2007. The effect of polysaccharides and sodium chloride on physical properties of processed cheese analogs containing whey proteins. Milchwissenschaft 62:59-62.

Heertje, I., M. J. Boskamp, F. van Kleef, and F. H. Gortemaker 1981. The microstructure of processed cheese. Neth. Milk Dairy J. $35: 177-179$.

ISO. 2004. ISO 5534:2004. Cheese and processed cheese-Determination of the total solids content (Reference method). International Organization for Standardization, Geneva, Switzerland.

Jost, R., R. Baechler, and G. Masson. 1986. Heat gelation of oil-in-water emulsions stabilized by whey protein. J. Food Sci. 51:440-444. 
Lee, S. K., S. Anema, and H. Klostermeyer. 2004. The influence of moisture content on the rheological properties of processed cheese spreads. Int. J. Food Sci. Technol. 39:763-771.

Lee, S. K., and H. Klostermeyer. 2001. The effect of $\mathrm{pH}$ on the rheological properties of reduced-fat model processed cheese spreads. Lebenson. Wiss. Technol. 34:288-292.

Lu, Y., N. Shirashoji, and J. A. Lucey. 2007. Rheological, textural and melting properties of commercial samples of some of the different types of pasteurized processed cheese. Int. J. Dairy Technol. 60:74-80

Marchesseau, S., and J.-L. Cuq. 1995. Water-holding capacity and characterization of protein interactions in processed cheese. J. Dairy Res. 62:479-489.

Marchesseau, S., E. Gastaldi, A. Lagaude, and J. L. Cuq. 1997. Influence of $\mathrm{pH}$ on protein interactions and microstructure of process cheese. J. Dairy Sci. 80:1483-1489.

McClements, D. J. 2005. Food Emulsions: Principles, Practices and Techniques. 2nd ed. CRC Press, Boca Raton, FL.

Meyer, A. 1973. Processed Cheese Manufacture. Food Trade Press Ltd., London, UK.

Mizuno, R., and J. A. Lucey. 2005. Effects of emulsifying salts on the turbidity and calcium-phosphate-protein interactions in casein micelles. J. Dairy Sci. 88:3070-3078.

Molins, R. A. 1991. Phosphates in Food. CRC Press, Boca Raton, FL.

Mulsow, B. B., D. Jaros, and H. Rohm. 2007. Processed cheese and cheese analogues. Pages 210-235 in Structure of Dairy Products. 1st ed. A. Y. Tamime, ed. Blackwell Publishing Ltd., Oxford, UK.
Piska, I., and J. Stetina. 2004. Influence of cheese ripening and rate of cooling of the processed cheese mixture on rheological properties of processed cheese. J. Food Eng. 61:551-555.

Savello, P. A., C. A. Ernstrom, and M. Kalab. 1989. Microstructure and meltability of model process cheese made with rennet and acid casein. J. Dairy Sci. 72:1-11.

Shimp, L. A. 1985. Process cheese principles. Food Technol. 39:6364., $66,68,70$.

Shirashoji, N., T. Abe, and K. Takahashi. 2006a. Influence of emulsifying salts on functionality of sliced process cheese. J. Dairy Sci. 89(Suppl 1):423. (Abstr)

Shirashoji, N., J. J. Jaeggi, and J. A. Lucey. 2006b. Effect of trisodium citrate concentration and cooking time on the physicochemical properties of pasteurized process cheese. J. Dairy Sci. 89:15-28.

Szczesniak, A. S. 1963. Classification of textural characteristics. J. Food Sci. 28:385-389.

Thomas, M. A. 1973. The Manufacture of Processed Cheese-Scientific Principles. 1st ed. New South Wales Department of Agriculture, Richmond, Australia.

Walstra, P. 1965. Light scattering by milk fat globules. Neth. Milk Dairy J. 19:93-109.

Zhong, Q., and C. R. Daubert. 2004. Kinetics of rennet casein gelation at different cooling rates. J. Colloid. Interface Sci. 279:88-94. 